\title{
Sexy selfie of hijabed women: Objectification of women's bodies in Instagram account @jilbabootd
}

\author{
Juliana Kurniawati \\ Departement of Cultural and Media Studies, Post-Graduate School, Universitas Gajah \\ Mada, Teknika Utara Street, Pogung Kidul, Sinduadi, Mlati, Sleman, Special Region of \\ Yogyakarta, Indonesia 55281 \\ e-mail: juliana08.saman@gmail.com
}

\begin{abstract}
Women with hijab often generate a controversy. Hijabed women in a sexy selfie are one example of it. The action of selfie photo becomes a new trend in line with the popularity of visual-based social media like Instagram. Taking and uploading selfie photos on Instagram seems to be indispensable for some people, including hijabed women. This paper is aimed to examine photos of sexy selfie of hijabed women uploaded in Instagram account @jilbabootd. The purpose of this paper is to reveal the practice of objectification of a women's bodies by analyzing the comments raised by followers of account @jilbabootd. This study is framed by Lacan's psychoanalytic theory of desire, lack, and pleasure. The @jilbabootd account is intentionally created for the purpose of the self-certified sexy self-certified photo shoot. Women who become an admin in the @jilbabootd account reproduce the discourse of male gaze. Women who become followers in this account also perpetuate the male domination of women by giving comments that the language is very male (manly). The hijabed women who send sexy selfie photos are "willingly" expose their bodies to become objects of male fantasy, gaze, and pleasure. They get their own pleasure by becoming the objects of gaze.
\end{abstract}

\section{Keywords}

desire, hijabed women, objectification, pleasure, sexy selfie

\section{Introduction}

Selfie (self-portrait) or swafoto in Indonesian is one of the popular phenomena, especially among social media users. Self-photographing activities have been known since the 19th century, although the term selfie itself only emerged in the 21st century. Self-portrait action (Selfie) began in 1907 in Naim, Scotland by a boy. This boy took a picture of himself in front of the mirror. The second photo found also depicts a man photographing himself in front of the mirror. The second photo was taken from a house in the Broughty Ferry area. The historical photographs included in the selfie photo characteristic are kept in the Royal Commission on the Ancient and Historical Monuments of Scotland (Azis, 2014, March 11).

The popularity of this selfie phenomenon since it is a lively trend done by social media users. The more people who do selfie upload it on social media. he more similar actions performed by other social media users that eventually become viral. Selfie action is favored by various 
circles from teenagers, adults, society, community leaders, and prominent leaders of the country. This selfie action that began in the 19th century becomes more popular with the support of increasingly sophisticated photography technology.

Communication technology continues to develop over time. Along with the rapid progress of communication technology in all aspects of human life, including the creation of online software application programs which also play a role in supporting the popularity of the selfie phenomenon. Social media networks connected to the internet connection as a tool that has the function to share information about ourselves. Through networks that are connected to through social media, we can inform people about things that are connected to us. Through social media, people know about us in their social media network (Nimda, 2012, March 1).

Various kinds of social media applications that exist today are Facebook, Twitter, Youtube, Google Plus, Instagram, Pinterest, Path, LinkedIn, Social "chat" Apps. Three social media that become the favorite netizen in Indonesia are Facebook, Instagram, and Youtube. Netizen is a slang term derived from the combination of the words "Internet" and "citizen". The term netizen is used to describe people who use the Internet to participate in or contribute to an Internet group or society (Oxford, n.d.). Facebook as the first favorite social media has the number of users as much as 71600000 (54\%). Second, Instagram with the number of users as much as 19900000 (15\%), then the third place occupied by Youtube with the number of users as much as 14500000 (11\%). The above data is the result of a field survey conducted by APJII (Association of Indonesian Internet Service Providers) in 2016 involving 2000 respondents. In addition, APJII also released a report on the number of internet users in Indonesia as much as 132700000 (Hidayat, 2016, October 24).

Instagram is a social media that was first released on October 6, 2010. It is a photo sharing app that allows users to take photos and apply digital filters in photos that have been taken. The photos are then distributed to various social networking services such as Facebook. Through Instagram, people can share things about their personal moments in the form of short photos and videos that can be accompanied by captions, tags for the intended person, and hashtag. The user status of photos they upload onto Instagram accounts can be easily viewed and accessed by connected people. Photo sharing trend on Instagram is not just sharing but also becoming an event of self-existence with many popular Instagram accounts. These Instagram accounts become pop up because of their uploaded photos, so they can have hundreds or even thousands of followers.

Instagram has the second largest user in Indonesia after Facebook. Instagram Indonesia users are dominated by women with a percentage of $63 \%$, while male users are only $37 \%$. The data is the result of a study of Instagram users in Indonesia conducted by TNS (Taylor Nelson Sofres) Indonesia at the beginning of 2016. Other findings presented are about the majority of Instagram users who have a high educational background (well educated) with a figure of $69 \%$ degrees holders (Herman, 2016, January 16).

Based on the results of these studies, women are more active through social media by displaying their image to their audience or commonly referred to Netizens. A wide range of social media enables the dissemination of self-image to various places as long as there is a signal for internet access online. Identity or self-image to be built is different on each woman depends on the various aspects of the underlying selfconstruction that they want to show off. The identity of women and men is constructed differently by the society. Men are described as the master who holds control over women as a determinant of women's behavior, as the dominant. While women are described as the other who is under control, dominated, submissive, and become objects in the outlet of desire or the desire of men. Nevertheless, women also reproduce male gaze by consciously or not.

Humans as social beings have a desire to be noticed, as a form of self-existence in the social environment. Similarly, women users of social media will perform self-representation therein. One way to represent is by capturing their personal moments in the form of images as one form of text. Where through the photo there is an exchange of meaning? As Hall stated (2003, pp. 1-2),

\footnotetext{
"Representation means using language to say something meaningful about, or to represent, the world meaningfully, to other people. Representation is an essential part of the process by which meaning is produced and exchanged

between members of a culture......representation is the production of meaning through language"
}

Ideal women who wear both hijab and non-hijab show self-image representation through selfie photos uploaded in social media, in this case, Instagram. A woman's self-image is displayed through a body that is dressed in such a way, takes her own photo, chooses the best picture, and uploads it on Instagram. The selfportrait activity is essentially private, but it becomes public property when self-images have been uploaded to Instagram. 
Selfie became a commodity form (Iqani and Schroeder, 2016, p. 1) global phenomenon and discourse (Veum and Undrum, 2017, p. 1). A search on photo-sharing app Instagram retrieves over 23000000 photos uploaded with the hashtag \#selfie (Giroux, 2015, p. 157). The selfie photo can be seen by people who connect with us because the photo is distributed in a social network that can be easily accessed using internet connection.

Selfie leads us to the fact that the self-perpetrator photo is the object of the gaze of anyone connected to the account owner. The whole body of the woman especially the front of the body becomes the object of fantasy for those who stare at her. Normally we encounter various selfie photos uploaded by women and men. The hijabed women also represent herself in the selfie. The hijabed women who do selfie to fulfill their wishes represent themselves in Instagram. They pose in a variety of photo styles. Sexy self-styled photo styles uploaded by women on the personal account and on the collection of photos of selfie we saw on Instagram. The hijabed women who do the selfie just to fulfill their desire represent themselves in Instagram. But in reality, it is not that simple, religious norms bind hijabed women in self-representation in public.

Because the photos are displayed in the form of sexy selfie photos even though they use covered clothes or dress but wear it so tightly as to highlight the curves of the body especially breast. The photo collection of sexy women selfies can be found on many accounts on Instagram, but this paper limits the review to only the @jilbabootd account to be analyzed. The reason for the selection of @jilbabootd account as a study material is because its admin is a female. Where on the other hand, similar accounts like @jilbabfanspage @jilboobs_strip, @jilbab_alim, and @cewek_jilbab_hijab_have male admins. The female admin on account @jilbabootd dare to show herself in the selfie photo contained in one of the collections of photos, in addition, the active followers give 'love' tag and comment on each posted photo.

Research on selfie has been conducted by Theresa M. Senft and Nancy K. Baym titled What Does the Selfie Say, Investigating a Global Phenomenon published in the International Journal of Communication 9 (2015). This research describes the journey of selfie as a global phenomenon (Senft and Baym, 2015, p. 1588). Another study related to selfie entitled The Self-and-The Transformation of The Public-Private Distinction by Michael James Walsh \& Stephanie Alice Baker is published in the Journal of Information, Communication \& Society (2017). This research describes the production and consumption of selfies by using the dramaturgical approach of Goffman, to explore how 'Self-presentation' takes place in the context of selfie (Walsh \& Baker, 2017, p. 1186). Concerning privacy is related to the role of the selfie and its impact on the boundaries between public domain and private domain in contemporary social life. While other articles are still related selfie entitled Self-representation and the disaster event: self-imaging, morality, and immortality by Yasmin Ibrahim published in Journal of Media Practice (2016). This article discusses the moral politics of misery and disaster-related to "disaster selfie and disaster porn", as well as online image ethics (Ibrahim, 2016, p. 211).

This paper is different from the three articles above where the focus in this paper is on the sexy selfie photo of the veiled woman who became the object of sexual fantasies for the staring. The question posed in this paper is how the women's bodies objectified in the @jilbabootd account? To answer this question, the writer will review and analyze the comments towards the sexy women photos on account @jilbabootd by using the Lacanian psychoanalysis approach of fantasy and desire. Moreover, it will also examine the possibility of the emergence of ambivalence among commentators.

\section{Findings and Discussions}

\subsection{Representation and Women's Identity on Social Media}

One form of representations made by social media users is to take pictures of the selfie and then upload it on social media accounts. As a form of self-representation, the selfie expresses a complex interaction between the identity politics, the objectification and the aesthetics of women themselves.

In the book titled Representation: Cultural Representations and Signifying Practices (2003, p. 15), Stuart Hall suggests that there are three ways of working language that is divided into three approaches: reflective approach, intentional approach, and constructionist approach. The constructionist approach is used in Cultural Studies. Constructivists do not deny the existence of the material world. However, it is not the material world which conveys meaning: it is the language system or whatever system we are using to 
represent our concepts (Hall, 2013, p. 25). The meaning is formed because of the social actors who construct the meaning based on the system of representation, cultural concepts, and the prevailing language. Therefore, those social actors make the world become meaningful and produce that meaning to others.

Representation becomes important in connecting meaning with culture. Hall (2003, p. 19) defines representation as an essential part of the meaning process produced and changed between members of the culture. In processes related to this meaning, there are two interrelated elements of the 'representational system'. The system that allows us to give meaning to the world by connecting a set of objects (people, objects, events and other objects) with conceptual maps.

In the constructed representation is not only the meaning but also the identity. According to Hall identity is an ongoing never-ending production, always within and not beyond the representation. Identity has a close relationship with representation. The meaning in the form of language and visual imagery will be associated with identity (Woodward, 1997, p. 12). In this way, identity is produced, consumed, and regulated in culture through representation (Woodward, 1997, p. 12). The construction of identity through that representation will be continuous and never finished because the identity is non-essentialist.

A female who wears hijab, her identity is generated by presenting self-representation wearing clothes with hijab in self-portraits that are uploaded in social media. Hijabed women in identities constructed by religious norms as women who are supposed to be subject to the rules of religion. Religious rules in dress and behave as stated in the Qur'an. Religious norms require women to appear polite in dress and minimize themselves in public.

\subsection{Desire and Pleasure in Lacan's Psychoanalysis}

Lacan in psychoanalytic theory argues about the relationship between desire with pleasures which is:

"The pleasure principle is the uncontrollable human drive to satisfy desire or an appetite for something that promises enjoyment, satisfaction, and pleasure in its attainment. Commonly recognized desires include yearning for sex, power, or food. If you stop to consider your own life, you'll realize that pleasure comes from many things we might not otherwise associate with it. For example, we often gain pleasure from purposefully breaking rules and laws or putting ourselves in situations that feel life-threatening. We can even gain pleasure from observing appalling or gruesome spectacles." (Ott and Mack, 2010, p. 151)

The pleasure principle is the uncontrollable human impulse to satisfy the desire for something that provides satisfaction and pleasure in achieving it. If the desire is not achieved, the lackness will occur within the person as a consequence that occurs when the subject enters the Symbolic. Castration also marks a loss in relation to the Symbolic (the lackness is always related to the tension between the Real and the Symbolic) (Handayani, et al., 2013, p. 63).

There is a kind of well-grounded and constitutive base of passionless desires. Without lack, the subject will never be a creature. The Phallus in Lacan psychoanalysis is the significance of desire and lackness (Handayani et al., 2013, p. 61). Men and women are defined differently by the symbolic order which is specified within the Phallic's function (phallic as signification/symbol of desire) (Handayani, et al., 2013, p. 59). This view is similar to that of Brian L. Ott \& Robert L. Mack (2010, p. 156): "This yearning for absent pleasures becomes a sense of lack, and Lacanian psychoanalysts claim that the lack of dominates the ways that we understand the life and the decisions we make."

Is the male obsession with the female body as a form of male's fear towards female? History proves that a woman's body has always been an object (Handayani, et al., 2013, p. 32). In the virtual world, the female body becomes the object of the gaze. The gaze embodies in the form of comments on social media. The written comments represent the desire, pleasure, and lack of the commentator.

\subsection{Selfie Photos and Women's Bodies on Instagram}

The word selfie became a word of the year in 2013. The meaning of selfie in Oxford online dictionary is A photograph that one has taken of oneself, typically one taken with a smartphone or webcam and shared via social media (Oxford, n.d.). From that meaning, we can conclude that selfie cannot be separated from the role of social media, because selfie itself is a photo taken by yourself by using a smartphone or webcam and then uploaded into social media accounts.

The results of research conducted by a number of German and Polish psychologists in researching the phenomenon of selfie photos show that women tend to do selfie than men. Research published by Medical Daily (Boreli, 2015, November 13) was conducted involving 1.200 male and female respondents. The results of this study indicate that male respondents in a month upload an average selfie photo of 3.3 times, 
while women as much as 6.7 times. This study suggests that extrovert and exhibitionist individuals tend to upload selfie photos more often (Gewati, 2016, October 7).

Judging from the aesthetic value, the selfie can be regarded as an art and beauty of personal self. It is like the women's character who love beauty. The women in hijab on Instagram display self-image through a body dressed up as non-hijab women. It is just that the hijab women have limits in the form of religious norms in presenting their image were not as free as women without hijab in dressing and displaying their body. Selfie photos of hijab women can be seen on some Instagram accounts that expose them as fashionable, beautiful looking women who adore beauty by dressing up with the latest style, a matching hijab, and smiling face to the camera. They also wear make-up in such a way, sometimes wearing natural makeup which reflects the simplicity of at least the modesty as their image they want to get.

However, in a search on some accounts on Instagram, the writer found woman photographs with hijabs in very sexy poses. Moreover, by further searching, the writer also discovered several accounts containing a collection of photos of hijab women in which all featured a sexy pose with a focus on a portion of the breast and buttocks. The photos showed a seductive facial expression or as challenging anyone who looked at the selfie photo. Those were women who upload selfie photos on Instagram as subjects who are aware that they became a spectacle in cyberspace. Selfie is aimed for others to feel amazed and interested when viewing our photos. A woman's desire to be admired and praised for her body is satisfied when she gets some 'love' tag and comments on the uploaded selfie photos. In this case, there is ambivalence between the hijab function as one of the tags of simplicity and piety with the desire of women who want to display his body sexily on social media.

About the desire, it is discussed in the book titled Restricted Subject. In the 20th century, the theory of desire for human experience is described by Merleau-Ponty as how desire and pleasure structure our experience, not only ourselves but also our world (Handayani, et al., 2013, p. 26). That is, desire and pleasure is a unity in our life experience with mind and body. In fact, Gabriel Marcel talks about the embodiment. Marcel rejects Cartesian dualism, the separation of mind and body on the grounds that the dualism destroys the self-unity and body. For Marcel, eliminating the body means abolishing oneself. Given the statement "I think" cannot be separated from the existence of the body, "I exist" is inseparable from the existence of my body (Handayani, et al., 2013, p. 27).

Based on the above statement, we can conclude that the existence of ourselves with our current behavior is the result of our desire and pleasure in the past that form from experience and social construction. Where if we live in a restrained tradition produced by religion and tradition will produce obedient bodies towards rules or can also extremely oppose the rule in order to pursue an insatiable desire and pleasure. This is in line with what Brian L. Ott and Robert L. Mack describe in the book titled Critical Media Studies:

"Pleasure does not refer only to aspects of life which we associate with comfort or joy........Pleasure then is that which seems to take us outside of ourselves." (Ott and Mack, 2010, p. 151)

"...we cannot fully articulate all of our desires and pleasures using language or symbols because many of these desires and pleasures are rooted in the imaginary, experienced before language and beyond linguistic expression." (Ott and Mack, 2010, p. 156)

\subsection{The Practice of Objectification on Women's Body on Instagram}

Selfie photos are one of the ways in which women are free to be themselves and women have the power to govern how they want to be seen by the public. Women represent themselves through beautiful selfie photos and then upload them on social media has become a common thing. The self-show is related to the identity you want to construct. Photo of self-educated women who show self-elegance in dressing and poses are also common on various social media accounts. However, the female selfie photo in the hijab with a sexy pose becomes something different. It is such a desire to free themselves from the confines of traditions and rules of religion which they belong. It becomes ambivalent when the selfie image is actually the object of the gaze, especially the male gaze, the object of sexual fantasy, desire, and pleasure.

The @jilbabootd account contains a collection of photos of hijab women, dressed in tight with sexy poses. On the @jilbabootd account, there are three photos of women who are not in hijab and three photos that do not belong to the selfie category and two short-standing videos. The view of the initial page of @jilbabootd account (Fig. 1). 
$\leftarrow$ jilbabootd

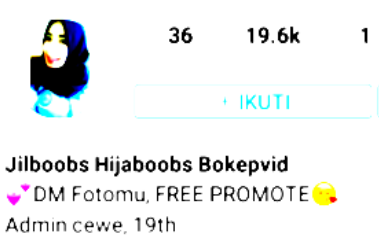

Fig. 1 Biography of @jilbabootd

This account is interesting to be analyzed and review, in addition, this account has a 19 y.o a female admin who uploads only 36 photos but has followers of 19600000 and only follow 1 account. This is public account not private, anyone can see the pictures without becoming a follower. This account has the majority of male followers and the account is active. Posted photos from the admin always get 'love' tag and comments from the followers. Unlike the admin on a similar account, admin on account @jilbabootd dare to show herself in sexy selfie photos.

This @jilbabootd account has rules for women who want their photos promoted for free by sending their photos via DM (Direct Message) to the admin. The first photo post on this account was uploaded on December 24, 2015. This photo featuring a sexy woman selfie photo which got 505 love tags and 4 comments. Promotions made with the aim of increasing the number of followers. The terms used as the language in comments on this account and similar accounts are CS (Chat Sex), PS (Phone Sex), VCS (Video Call Sex), BO (Booking Out), DM (Direct Message), Sange (the abbreviation of sakaw ngewe which means horny). These terms can be found in the comments column. Comments that use this term can be interpreted as people who are familiar with the used languages and use it for a long time.

The phenomenon of sexy hijab or commonly known as jilboob is actually not a new thing. The rise of jilboob type worn by women as we can see in our daily life, but a collection of sexy selfie photos co-ordinated by the admin is purposed as sort of showcase sexy new style body on the smartphone. The hijab women who send their self-portrait to the admin in a conscious position when the photo they send to the @jilbabootd account is published, which is in the public domain and will be an object of sexual gaze and fantasy especially for males.

Based on the search results of the comments on the @jilbabootd account can be described as follows: The female body part of this account most widely fancied is breast. This is reflected in the number of love tags obtained by a photo if the selfie picture that accentuates the breasts, in addition, to getting a lot of love tags also get nice comments from women but the majority of comments come from men. A woman selfie photo with the tight cloth with a bunch of breasts and seductive smiles gets the most love tag than women do not expose their breasts. Love tags earned 1278 , with 87 comments.

Comments on the photo above were written by males whom mostly invite for CS, PS, VCS on the women as well as comments about breast and sex. The men offer to give satisfaction to women who are sange (horny)(Fig. 2 a \& b) even with the promise of privacy guaranteed (Fig. 2 d). In the comment field to the selfie photo above there are two interesting comments to be discussed are comments from @sister_in_Islam and @curhat.asik account. The account @sister_in_Islam has commented "Don't you ashamed, audzubillah" (Fig. 2 c). The owner of the latter account may be advising the commentators or advising the @jilbabootd account admin or women in the photo or may be unaware of the purpose of this account. The @jilbabootd account is purposely created as a means for women to liberate where in their daily lives are confined wherein cyberspace they can satisfy their inner lackness. While commenting : "yang hijab emang lebih menggoda (wearing hijab is more seductive)" (Fig. 2 b), there are some similar comments in this account where male sexual fantasies tend to be wilder and enter into the realm of deeper sexual fantasies when meeting women or seeing photos of women in covered clothes but showing body and curves. Fantasy towards the covered ones is more desirable at least on this @jilbabootd account. 
a

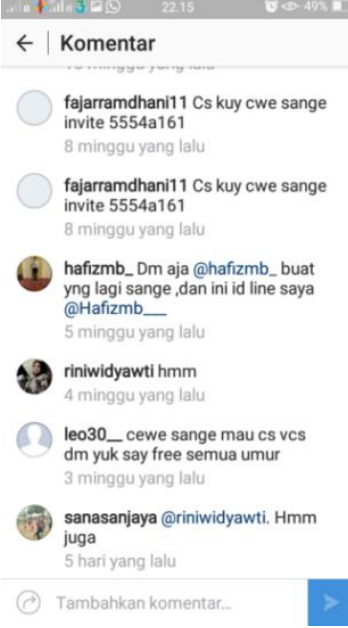

C

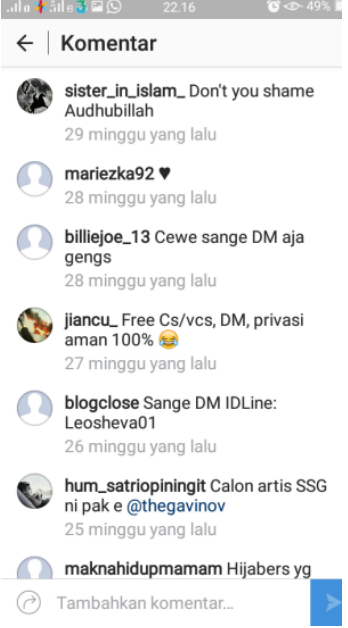

b

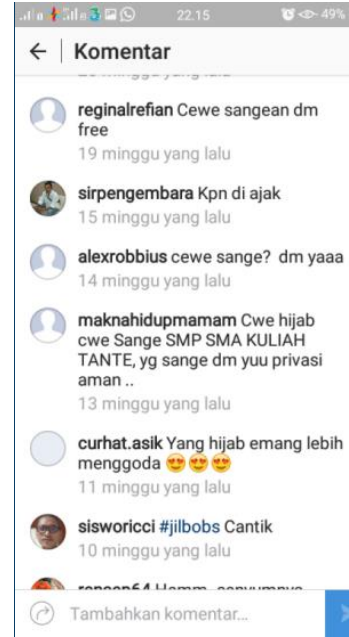

d
$\leftarrow \mid$ Komentar
a mingyu yang latu
abeeng333 sayangg cs yu dijamin aman ko privasi nya 14 minggu yang lalu
stwnfbri Cewe sange dm me 13 minggu yang lalu
maknahidupmamam Cwe
hijabsange dm yu.. Privasi aman 13 minggu yang lalu
(2.) momonmesi Halo Bu cantik 13 minggu yang lalu
13. redo4834 Sluruuuup 9 minggu yang lalu
kabutsenja88 sangek .. bj dong kk 9 minggu yang lalu
8 tesalonikaaaaa4 Waw 4 minggu yang lalu

Fig. 24 Examples of comments in @jilbabootd's post; a comment about sange, b comments about sange, $\mathbf{c}$ opposite

comments, and $\mathbf{d}$ comments about privacy

The women's photo in @jilbabootd is equally beautiful and attractive with a trendy dress. The difference between them is visible where the image of female selfie dressed in the orange shirt is more focus on her breast than her face while the selfie picture of women in the blue dress is more accentuate on her face (Fig. 3). 


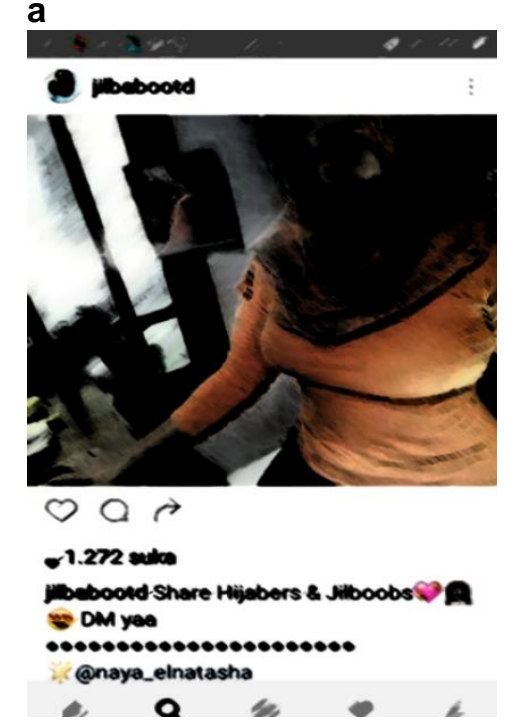

b

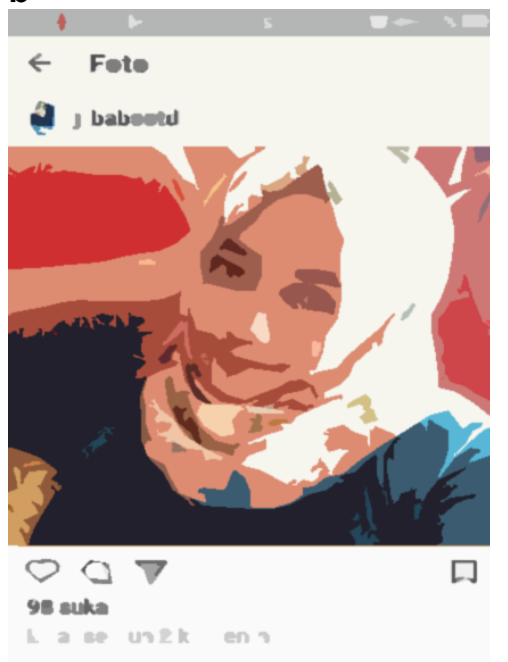

Fig. 3 The comparison between two posts which has maximum and minimum love tag; a a post has maximum love tag, $\mathbf{b}$ a post has minimum love tag

Based on Fig. 3, it arises the question what exactly the role of a piece of cloth called hijab here for the followers of @jilbabootd account especially for the commentators of men or women? A piece of headscarf called hijab in the @jilbabootd account becomes an erotic and sexual fantasies object especially for men, but women also participate in perpetuating the fantasy with sexy self-portraits. In some comments, women find reproducing male gazes by commenting on the picture. @shinta_syintiar account says "try CS ahh, DM please". The other account named @rizkivizcara say "I am sange, DM". It means that administrator of @jilbabootd account also reproduces male gaze by creating this account. The views written in the comment column are very manly.

The comments written by the followers have women who are in hijab as objects of desire, the erotic objects of their sexual fantasies, in this case primarily men because the majority of commentators are male. Male gets satisfaction when looking at photos of sexy women selfie in hijab, also they will be more satisfied if the invitation for CS, PS and VCS are fulfilled by the intended woman. Thus, the decision remains in the hands of women. The desire to look at this self-willed female selfie photo will continue to appear, and it takes a fantasy to desire to not disappear and also not to arise lackness in oneself. Fantasy of erotic objects that arise comes from the majority of men and some women. Women who post photos on the Instagram account have a desire to be in the male gaze. When they are viewed then the pleasure of these women are fulfilled. This is evident from the postings of repeated pictures by women who get the love tags.

Ambivalence occurs in comments that appear to the picture that mostly lead to sexual fantasies but there are some whose comments suggest giving advice. The opposite comment is exposed by @tazaeni account which say "dooms day, astagfirullah". @tamamikhai account also comment "iisss, disgusted in hijab with sex brain, sweetness outside and bitterness inside". @riyanti_muslim_center account said " what is the purpose of this account? Many photos are not worth seeing " (Fig. 4). 


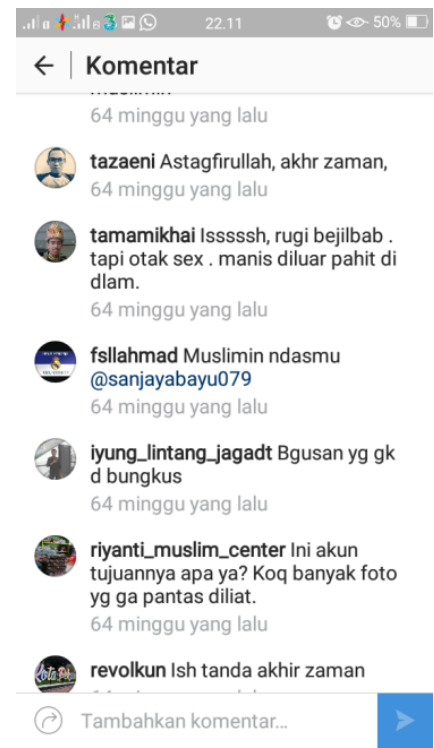

Fig 4 Comments in account @jilbabootd

When talking about fantasy, it is related to psychoanalysis when there is desire and then there is lack, the fantasy is kept in order that desire does not become lost. Through fantasy, we find relief from our desires and are able to experience a pleasure in satisfaction. Through fantasy, one may deny the rigid oppression that our social reality subjective identities. For this reason, fantasy itself contains the potential for the transgressive reconstitution of both identity and culture (Gardiner, 2014, pp. 2-3). Fantasy is also related to the issue of pleasure, comments given by followers associated with unconscious or the subconscious wherein the offline world the desire of sex fantasy is confined, cannot be released, while in the realm of online hidden desire is emerged and satisfied this the lack is in self-covered.

\section{Conclusions}

Selfie or swafoto as an existing phenomenon had existed in the 19th century. Selfie favored by various circles, female, male, young and old. Various selfie poses done by fans ranging from selfie place in the usual place to the extreme place, ranging from selfie pose in general to the sexy selfie pose. Photos of selfie uploaded onto @jilbabootd instagram account and the comments that appear to accompany the photo for the study in this paper.

From the search results to the comments on the @jilbabootd account can be summarized as follows: account @jilbabootd is intentionally created for the purpose of self-objectified women's selfie photo. Moreover, the woman who becomes the admin in the @jilbabootd account reproducing the discourse of the male gaze. Women who become followers in this account also perpetuate the male domination of women by giving comments that the language is manly. The veiled women who send a sexy selfie photo "willingly" give up her body to become an object of male gaze and pleasure. Hijab and the tight clothes they wear would be the object of sexual fantasy that will continue to meet the desire of the people who look at them. In the online world, even relations between women and men tend to be unbalanced. Descartes argues that women have no cogito power but doubt (or doubted?) of their sexual identity because they are defined as a woman by society. Descartes, therefore, defines I for a woman but it is from I think (Handayani, et al., 2013: 29). That happiness occurs in the most likely comments leading to sexual fantasies but there are some who comment by giving advice statement. In addition to men, women in this account also have the desire and pleasure to become an object that is aimed to be viewed.

Acknowledgments The authors would like to thank my lecturer Ratna Noviani, Ph.D for her valuable support. 


\section{References}

Azis, I. (2014, March 11). Foto selfie eksis sejak tahun 1800-an [Selfie exist since 1800]. Sidomi. Retrieved from http://sidomi.com/272005/foto-selfie-telah-eksis-sejak-tahun-1800-an/

Boreli, L. (2015, November 13). Selfie addiction: People who post self-portraits on social media are extroverted, social exhibitionists. Medical Daily. Retrieved from https://www.medicaldaily.com/selfieaddiction-people-who-post-self-potraits-social-media-are-extroverted-social-361504

Gardiner, R. M. (2014). Desire and fantasy: The conditions of reality between the Self and the Other. Graduate School of Art Theses. ETD 22.

Giroux, H. A. (2015). Selfie culture in the age of corporate and state surveillance. Third Text, 29(3), 155164. doi:10.1080/09528822.2015.1082339

Gewati, (2016, October 7). Hasil riset Pribadi "ekstrover" dan "eksibionis" penggemar berat "selfie" (Research result extroverted personal and exhibitionist very fond of selfie). Kompas.com. Retrieved from https://lifestyle.kompas.com/read/2016/10/07/160357620/hasil.riset.pribadi.extrover.dan.eksibisio nis.penggemar.berat.selfie/

Handayani, C. S., Arivia, G., Haryatmoko, Robet, R. (2013). Subyek yang dikekang [Restricted subject]. Jakarta, Indonesia: Salihara

Hall, S. (2003). Representation: Cultural representations and signifying practices. London, England: Sage

Hidayat, M. W. (2016, October 24). Tiga media sosial favorit pengguna internet Indonesia (Three favorite media social of Indonesian internet users). Liputan 6. Retrieved from https://m.liputan6.com/tekno/read/2634027/3-media-sosial-favorit-pengguna-internet-indonesia

Herman. (2016, January 16). Pengguna Instagram di Indonesia mayoritas perempuan (Female users Instagram majority in Indonesia). Beritasatu. Retrieved from http://www.beritasatu.com/iptek/341956-user-instagram-in-indonesia-mayoritas-perempuan.html

Ibrahim, Y. (2015). Self-representation and the disaster event: self-imaging, morality, and immortality. Journal of Media Practice, 16(3), 211-227. doi:10.1080/14682753.2015.1116755

Iqani, M. \& Schroeder, J. E. (2016). \#selfie: Digital self-portraits as commodity form and consumption practice. Consumption Markets \& Culture, 19(5), 405-415. doi:10.1080/10253866.2015.1116784

Nimda. (2012, March 1). Apa itu sosial media (What is media social). Unpas. Retrieved from http://www.unpas.ac.id/apa-itu-sosial-media/

Webopedia. Netizen. Retrieved from https://www.webopedia.com/TERM/N/netizen.html

Ott, B. L. \& Mack, R. L. (2010). Critical media studies. London, England: Wiley Blackwell

Oxford. (n.d.). Definition of selfie in English. Oxford Living Dictionaries. Retrieved from https://en.oxforddictionaries.com/definition/selfie

Senft, T. M. \& Baym, N. K. (2015). What does the selfie say? Investigating a global phenomenon. International Journal of Communication, 9, 1588-1606.

Veum, A. \& Undrum, L. V. M. (2017). The Selfie as a global discourse. Discourse and Society, 29(1), 86-103. doi:10.1177/0957926517725979 
Walsh, M. J. \& Baker, S. A. (2017). The selfie and the transformation of the public-private distinction. Information, Communication \& Society, 20(8), 1185-1203. doi:10.1080/1369118X.2016.1220969

Woodward, K. (ed.) (1997). Identity and difference. London, England: Sage 